\title{
Creative self-presentation skills among students in the educational process of a higher education institution
}

\section{Habilidades creativas de auto-presentación entre los estudiantes en el proceso educativo de una institución de educación superior}

Olga A. Poselennova

diskprof@list.ru

https://orcid.org/0000-0003-0035-4397

Lecturer, Automechanical Technical School, Ulyanovsk State University (Russia)

\section{Margarita A. Kovardakova}

diskprof@mail.ru

https://orcid.org/0000-0002-6624-8477

Candidate of Pedagogical Sciences, Dean of the Advanced Teachers Training Faculty, Ulyanovsk State University, (Russia).

Irina V. Aryabkina

aryabkina68@mail.ru

https://orcid.org/0000-0002-8765-2153

The doctor of pedagogical sciences, professor of the Ulyanovsk State Pedagogical

University, professor of the Ulyanovsk State University (Russia).

\section{Yulia A. Chernova}

yu.chernova@mail.ru

https://orcid.org/0000-0002-6775-4566

Candidate of Pedagogical Sciences, Docent of the Department of mathematics and physics of the Ulyanovsk State Agricultural University named after P.A. Stolypin,

Russian Federation

Kirill O. Ravodin

ravodinkiril@yandex.ru

https://orcid.org/0000-0002-8375-9527

$\mathrm{PhD}$ in Physics and Mathematics, Associate Professor, Head of the Development of Innovations and Entrepreneurship Department of the Ministry of Economic Development and Industry of the Ulyanovsk Region (Russia)

Recibido: 02/05/21

Aceptado: 28/06/21

\section{Abstract}

The purpose of the study is theoretical and methodological justification and modeling of the process of formation of creative self-presentation skills among future specialists in the field of mass media at the university. A list of skills that determine the effectiveness of 
creative self-presentation is based on the analysis of works on self-presentation and professional standards of specialists in the field of mass media. The study revealed the specifics of the process of forming these skills at the university. The paper describes a developed by the authors model for the formation of creative self-presentation skills, the effectiveness of which was tested experimentally, a system of technologies and pedagogical conditions for its implementation is proposed. The results obtained in the course of the study are of practical importance, both for educational institutions of higher education, which train specialists in the field of mass information activity, and directly for specialists, whose integral part of work is the creative component.

Keywords: self-presentation, creative self-presentation, specialist in mass information activities, professional communication, formation of skills, creative self-presentation.

\section{Resumen}

El propósito del estudio es justificación teórica y metodológica y modelización del proceso de formación de habilidades creativas de autopresentación entre los futuros especialistas en el campo de los medios de comunicación en la universidad. Una lista de habilidades que determinan la efectividad de la autopresentación creativa se basa en el análisis de trabajos sobre autopresentación y estándares profesionales de especialistas en el campo de los medios de comunicación. El estudio reveló los detalles del proceso de formación de estas habilidades en la universidad. El artículo describe un modelo desarrollado por los autores para la formación de habilidades creativas de autopresentación, cuya efectividad fue probada experimentalmente, se propone un sistema de tecnologías y condiciones pedagógicas para su implementación. Los resultados obtenidos en el transcurso del estudio son de importancia práctica, tanto para las instituciones educativas de educación superior, que forman especialistas en el campo de la actividad informativa masiva, como directamente para los especialistas, cuya parte integral del trabajo es el componente creativo.

Palabras clave: autopresentación, autopresentación creativa, especialista en actividades de información masiva.

\section{Introduction}

At present, various innovations are being implemented in the educational sphere regarding the content of education, its organization, methods, forms, etc. They have a significant effect on the system of training specialists at a higher education institution for future professional activities and are determined by the requirements of the labor market. Today, those specialists are in demand who have aptitude for self-development developed at a high level, an aspiration for self-actualization, with a system of competences required for the implementation of professional activities at a creative level. But even if a specialist has creative potential and motivation to be creative, this does not 
Olga A. Poselennova, Margarita A. Kovardakova, Irina V. Aryabkina, Yulia A. Chernova, Kirill O. Ravodin.

mean that such a specialist can be successful. A form of expression appropriate to the professional field is needed to manifest creative potential.

Professional self-presentation is an inseparable part of a person's positioning as a specialist. There are a number of definitions of professional self-presentation. In particular, A.K. Kasatkina treats it as a positive presentation by the subject of such qualities which, in his opinion, are relevant to perform professional actions in this field. In this connection, the study of specific ways of professional self-presentation seems to be important (Kasatkina, 2011). However, the mechanisms of creative self-presentation are still poorly studied.

There are a number of works on the problem of teaching a person successful selfpresentation is represented by the works that offer fairly holistic didactic systems: methods, technologies, models of teaching self-presentation at almost all levels of education in Russia: preschool, primary and general secondary, primary and secondary vocational, higher education. But there are no works devoted to the formation of creative self-presentation skills among future specialists in mass information activity, with the exception of the work of L.M. Semyonova, concerning PR specialists. The specificity of their activities, aimed at collecting, processing and disseminating relevant social information in press, on radio, television, in cinema periodically, requires a number of special professional skills from specialists in this field. Starting communication with a person who possesses the required information, a specialist in mass information activities should be able to win the interlocutor's favor, position himself as an expert in a certain topic, problem. This is always a non-standard personality, charismatic, capable of attracting the attention of the audience, arousing its interest and trust (Pochkai, 2016).

The foregoing emphasizes the need for a deep study of the problem of the formation of creative self-presentation skills in students preparing for professional activity in the studied area, and the solution of obvious contradictions:

- between the social order for training a specialist's personality who is able to find creative ways for self-expression, and the lack of a methodological basis for the formation of a future specialist who meets these requirements in the educational process of a higher education institution;

- between the need to train future specialists in mass information activity to perform professional functions, the positive outcome of which depends on the degree of mastering skills, techniques and methods of self-presentation by students, and the insufficient level of readiness, the degree of preparation of pedagogical means that should be used in the educational process of a higher education institution, forming students' readiness for creative activity and creative self-presentation.

The indicated contradictions made it possible to formulate the problem of research as follows: what are the theoretical and methodological foundations, technological approaches and pedagogical conditions for the formation of creative self-presentation 
skills among students - future specialists in the field of mass information activities in the educational process of the university?

In the main part of the paper in the theoretical framework block the professional communication of specialists of the mass media profile is considered in the problem field of a competent approach, the degree of development of the problem in domestic and foreign literature is described, the essence of creative self-presentation as an element of professional communication of a specialist in the field of mass media is revealed, the specifics of the formation of creative self-presentation skills of students in the educational process of the university is described.

The methodological framework block of the paper describes a model of the process of developing creative self-presentation skills of students, pedagogical technologies, as well as criteria, indicators and dynamics of the formation of creative self-presentation skills of students - future specialists in the field of mass information activities.

The results block summarizes the results of the study, proving the effectiveness of the selected methods.

\section{Theoretical Framework}

In domestic science, self-presentation as an independent phenomenon has been studied since the early 1990s. Research into the process of formation of readiness for selfpresentation in Russia began in the 2000s. One can distinguish two research approaches in this scientific area: socio-psychological (the psychological foundations of teaching selfpresentation are studied) and socio-pedagogical (didactic aspects of teaching selfpresentation are considered) (Koryagina, 2012). Let us give a brief description of the works related to the first area. Socio-psychological training is proposed as a means of teaching self-presentation in the context of improving the image of commanders of cadet sub-units (Savateyev, 2001). In the fundamental work of Yu.M. Zhukov "Training as a method of improving communicative competence", this form of activity is considered as an effective way of developing self-presentation skills, since it stimulates the activity of its participants (Zhukov, 2003).

The author's techniques have been proposed to teach adolescents the methods and techniques of self-presentation for solving psychological problems at this age (Gretsov, 2003). The characteristics provided by E.V. Mikhailova of methodological aspects of doing exercises during the training is valuable for our research (Mikhailova, 2006). There is a study of the specific features of communicative actions during self-presentation among female employees in a military group (Ponomarenko, 2008). E.Yu. Krylov's work is devoted to teaching various self-presentation tactics of students during communication in a virtual environment. (Krylov, 2012). E.V. Kazantseva, considering educational psychologists' self-presentation as a professional meta-skill, uses the methods of brainstorming, group discussions, game modeling of professional activity for its 
development (Kazantseva, 2013). The authors such as N.G. Novitskaya and I.N. Barash propose to conduct communication training in a situation of intercultural communication. Researchers taught students self-presentation at foreign language (English) lessons (Novitskaya, Barash, 2014).

In the study undertaken by E.E. Glotova it was proved that training contributed to the expansion of students' ideas about the chosen profession and it is an effective means of developing the skills of self-presentation and managing the impression of oneself (Glotova, 2015). Thus, one can draw a conclusion that representatives of the sociopsychological area of teaching self-presentation are considered as a new subject area of psychological theory and practice, they choose socio-psychological training as its means and associate the learning process with the development of communicative competency. The socio-pedagogical area of self-presentation is represented by the following research. Self-presentation is considered as a certain behavior of the subject, therefore, teaching self-presentation should be pragmatic in character and reduced to shaping students' experience of a certain type of behavior, developing a conditioned reflex in students, appropriate behavior models. Such teaching methods are proposed as 30-second selfpresentations, group presentations on specific topics, writing a $\mathrm{CV}$, etc.

In the thesis research carried out by I.B. Zakharova theatrical pedagogy is offered as a pedagogical means of developing self-presentation skills, and as methods - counseling, preparing a CV, conducting rehearsals, acting out interview situations in a recruiting agency. The author has developed a complex of communicative-verbal games, socially significant situations of self-presentation. In the author's opinion, "the effective orientation of a student's personality towards successful self-presentation is determined by the development and implementation of the author's program of socio-pedagogical orientation of the student's personality towards successful self-presentation; "the enrichment of the student's personal experience of self-presentation by means of theatrical pedagogy; the creation of socially significant real situations of self-presentation of the student's personality by communicative verbal means" (Zakharova, 2003). The specific features of self-presentation of preschool children with speech development disorders were studied by K.E. Panasenko. "Learning through experience" was chosen in various types of children's activities as a form of teaching self-presentation (Panasenko, 2005). O.V. Sheverdina, in her research, studied teenage behavior at a summer camp. To teach self-presentation, the author used situations in which teenagers and adolescents can communicate freely and naturally, expressing themselves and their interests (Sheverdina, 2006, p. 23).

The thesis research conducted by L.M. Semyonova is devoted to the formation of readiness for self-presentation of future specialists in public relations. The author substantiated a complex of pedagogical conditions for raising the readiness level of future specialists in public relations for self-presentation. This complex implies the creation and enrichment of the educational environment with professional values in accordance with the main parameters of students' readiness for self-presentation, as well as the implementation of a comprehensive program for the development of students' readiness 
Gduweb

Revista de Tecnología de Información y Comunicación en Educación • Volumen 15, Nㅜ 2. Mayo-agosto 2021

for self-presentation in educational and extracurricular activities, development of a monitoring system to determine the level of readiness of a future specialist in public relations for self-presentation (Semyonova, 2008). Considering the specific features of the formation process of readiness for self-presentation among students studying at a higher education institution of tourism, A.Yu. Brigadnova offers a theoretical course that reveals the basics of self-presentation "in the process of active lectures, which use questions, case analyses, fragments of discussions, audio and video materials. In practical classes, various elements of self-presentation are tried out in a variety of professional situations (Brigadnova, 2012).

The paper by M.G. Shishkova is devoted to teaching self-presentation of future workers in the process of their professional development. In the learning algorithm, the author distinguishes the following steps: introductory and evaluative ones implemented through the development of communicative and praxeological skills of self-presentation by the student; a factual one, directed at honing self-presentation actions; an organizational and activity one, associated with the development of self-presentation skills. The learning process ends with a public creative self-presentation in a team format (Shishkova, 2013). V. A. Savin's dissertation research is devoted to the study of didactic conditions for the development of self-presentation among high school students. During the experiment, students were asked to solve "meaning-making tasks". Such tasks motivated the subjects to find solutions based on their personal aspiration to present themselves in a certain (positive) way (Savin, 2012). Self-study work is considered as a means of developing students' self-presentation skills in the educational and methodological manual "Developing practical skills for life safety, success in employment and career" by such a team of authors as S.P. Budnikova, S.A. Radchenko, N.V. Prosperova and others. As self-study work, students are offered such tasks as writing an essay, preparing for a discussion, a debate, business games, preparing a presentation on a topic, a project, solving cases (Budnikova, Radchenko et al., 2016).

Among the works of the second area, one cannot help mentioning the textbook published in 2018 by A.A. Klimenko, S.A. Khazova, S.A. Karasyova about self-presentation competency, its content and the bases of formation. Self-presentation activity is considered by the authors as a modern direction of training specialists, and selfpresentation competency is called the personal quality of university graduates competitive on the labor market. The authors substantiated the didactic principles of the formation of self-presenting competency in a higher education institution, characterized the stages of the formation of self-presenting competency (Klimenko, Khazova et al., 2018). One of the latest works in the social and pedagogical direction is I.I. Mishina's thesis dedicated to the design and implementation of a professionally oriented model that ensures the formation of readiness for speech self-presentation of students studying in nonhumanitarian areas. In the author's opinion, "the effectiveness of the designed model of teaching speech self-presentation is determined by the introduction of interactive methods and forms, as well as the integration of pedagogical and andragogical teaching models" (Mishina, 2018, p. 71). 
Defining the professional communication of a future specialist in mass information activity as a constituent part of his professional competency, in this paper we consider specific features of the process of creating a system of actions for a future specialist's creative self-presentation in a certain field in the educational process of a higher education institution. Any activity of a person can be performed only with the skills and abilities. Professional activity, as a more complex form of knowledge and behavior, requires a special increased level of their command. The assessment of the professional activity of a specialist is carried out proceeding from the quality of his application of the knowledge and skills acquired. It is known from psychological science that skills are formed as a result of repeated, systematic, purposeful repetitions of certain actions, which brings their performance to automatism (Avdeeva, 2009, p. 365). Automatism is required to reduce the time used to perform an action and reduce the mental burden on the performer. However, it is inappropriate to speak about the elimination of the controlling function of the subject's consciousness: a change in any parameter of work entails the instantaneous activation of awareness.

Skills refer to specific ways of doing things. Automatic performance of actions frees the mind of control over mental, sensory, motor operations that provide the implementation of a specific action. From an operational point of view, such an action becomes automatic, which allows consciousness to pay more attention to the ultimate goal of the action being performed, its conditions and results. From this it follows that the degree of awareness of actions becomes higher, therefore, it can be concluded that training leads to "the inclusion of a skill in the structure of a person's conscious activity" repetitions of certain actions, which brings their performance to automatism (Avdeeva, 2009, p. 367). Skills, as wellformed and stabilized modes of action, include several components: motivational, cognitive (building modes of action, conditions, image of the space in which the activity is carried out), executive, volitional, etc. Intellectual, sensory, motor (motor), sensorimotor and other types of skills are identified. The requirements for the learning process organization also change depending on what skills are formed in learners. But their interest in activities, demonstration, explanation, creation of attitudes to master skills are general conditions for the formation of any skills. The skill formation process is largely determined by learning technology.

The process of the skill formation is described in detail in N.A. Bernstein's work "On the construction of movements". The skill formation process is made up of four stages:

1. Preliminary, or introductory. A certain skill acquisition program is being formed. Actions are broken down into components, they are repeated several times in a test mode. Even with a clear understanding of the goals, there are numerous mistakes in actions.

2. Analytical or preparatory. A person analyzes the various parameters of the implementation of elements. Separate actions are formed, their alternation appears. Actions are characterized by a high level of focused attention. 
3. Synthetic, or standardizing. The person has a clear idea of the skill. The individual elements of a holistic action are combined into a single whole. The quality of actions is improved. There is a shift of attention from action to its result.

4. Automatic, or situational. The person adapts the action to the situation, arbitrarily regulates it. All unnecessary elements of the action are removed. The action assumes an expedient character (N.A. Bernstein, 2012, p. 35).

In the theory and practice of teaching skills there are different approaches. With respect to the formation of professional skills, the most appropriate one is the activity approach (Abulkhanova-Slavskaya, 1991, Davydov, 2004, etc.). In accordance with it, in the learning process, it is necessary:

- to plan the characteristics of the professional activity being formed as a specific work skill;

- create conditions that allow the learner to accept the learning task;

- to design a program of activities contributing to the formation of an orientation basis of professional skills in the given characteristics, to create a regulated orientation in the process of their mastering;

- to organize the mastering of activity as a process of its internalization, forming the required characteristics at each stage of this process;

- to provide control over the process of formation of activities and its correction. When organizing the process of forming the creative self-presentation skills among future specialists in mass information activity, the ideas of the concept of the mental action development were relied on, since the first attempts to form skills systematically were made on its basis (Galperin \& Talyzina, 1972. According to this theory, the sequence of learning based on the activity approach consists of five stages: the formation of an orientation basis for future action; practical mastering of mental action, which is carried out using objects; mastering a given action without relying on real objects; a shift of the action performance of external speech entirely to internal speech; performing an action completely in the internal plan with appropriate reductions and transformations, with the transfer of the performance of this action from the sphere of consciousness (that is, constant control over its implementation) to the sphere of intellectual skills.

Proceeding from the characteristics of the activities of specialists in the field of information and communication activities the composition of skills and qualities of creative selfpresentation were determined as follows:

- skills and abilities of establishing contacts, keeping the listener's attention;

- the ability to win other people's favor, demonstrating respect and trust in the interlocutor, sincerity, spontaneity, interest;

- introspection skills (quickly and accurately recognize the qualities and state of the interlocutor, orientation in communication to the interlocutor's reaction);

- skills of self-reflection (to take an "external" position in consciousness in relation to "one's own Self" and thinking); 
- self-regulation skills (management of one's psycho-emotional state);

- skills of verbal communication (accurately formulate thoughts, express them in a language accessible to the interlocutor, have one's own speech style, master various speech tactics, skills of speaking and writing, good diction, intonational expressiveness of speech, a large vocabulary, etc.);

- skills of civilized psychological influence (well-reasoned open influence, addressed to the intellectual abilities of a person, free from force and deceit);

- skills of non-verbal communication (control of facial expressions, gestures, movements, visualization of one's own qualities and merits (visual image);

- possession of various tactics of creative self-presentation;

- the ability to concentrate on a person, his emotions and feelings (social intelligence);

- skills of mobilization and adaptation to the communication situation;

- artistic skills (improvisation, persuasiveness, the ability to transform);

- business etiquette skills (identifying the topic, drawing up a plan for self-presentation, greeting, answering questions, completing communication).

A theoretical model that has a process nature was developed to form the listed skills of creative self-presentation. It gave an opportunity to consider the process under study comprehensively identifying the following interrelated blocks.

The target block comprises the goal and objectives of the process under study. The goal is to develop students' skills of creative self-presentation as a component of professional communication. The goal breaks down into the following objectives: the formation and development of a student's motivator system; stimulation of self-development and selfactualization of the student; encouraging attempts of the subject of education at creative self-expression; development of such important qualities as creativity, openness, tolerance, sensitivity, courage, etc. in a student.

The methodological block of the model reflects the approaches and principles to the formation of students' creative self-presentation skills as an element of professional communication in the process of training a future specialist in mass information activity.

The process of forming self-presentation skills is built in accordance with a number of methodological approaches: culturological, axiological, systemic, personality-activity, competence-based, content-related and poly-artistic, and relied on the principles of cultural conformity, productiveness, multiculturalism, unity and harmonization of rational and emotional factors, the relationship of sociocultural and educational values, integrity, variability, activity, complexity, etc.

The content block of the model is represented by such disciplines as the basics of communication theory, communication management, professional ethics, intercultural communication and the media, speech technology, psychology and labor psychology. 
The discipline that deepened and generalized the knowledge and skills of students in the field of self-presentation was the special course "Technology of creative self-presentation within the professional communication of a specialist in mass information activities". The purpose of the special course is to master the mechanisms of creative self-presentation and business communication by students as a component of the professional activity of a specialist in mass information activities. During the special course, the following objectives are achieved: deepening and expanding students' knowledge about the essence of self-presentation, the specificity of creative self-presentation, mastering various strategies and tactics of self-presentation, improving the skills of verbal and nonverbal communication in the context of business communication; study of national and gender characteristics of verbal and non-verbal communication in business communication of a specialist in the field of mass media; the formation of the skills of introspection and self-reflection, the acquisition of skills in the methods of creating a positive image.

The special course provided the formation of such competences as:

- universal (the ability to carry out business communication in oral and written forms in the state language of the Russian Federation and foreign language (s));

- general professional (the ability to create media texts, media products, communication products that are in demand by society and the industry in accordance with the norms of Russian and foreign languages, the characteristics of other sign systems; the ability to use modern technical means and information and communication technologies in professional activities);

- professional (the ability to choose adequately the form of work with opponents based on the goals of communication, initiate and maintain contact with the audience, use modern information technologies and media to raise the effectiveness level).

The content of the special course is structured into the following sections: "Models and methods of business communication of a specialist in mass information activities", "Selfpresentation as a factor in the formation of a positive image of a specialist in the mass information sphere", "A resume and an interview: a method of preparing and conducting", "Adaptation methods in a new team in the field of mass media", "Career planning for a specialist in mass information activities".

The activity block is represented by pedagogical technologies for the formation of creative self-presentation skills among students in the process of training a specialist: lectures (traditional and innovative lectures), games (role-playing game), interactive technology (case studies, portfolio, storytelling). Pedagogical technologies were selected according to such criteria as conceptuality (reliance on a specific scientific concept); consistency (possession of all the features of the system), controllability (opportunities for goal-setting, planning, educational process, monitoring, variation of methods and means of teaching in order to correct its results), efficiency (efficiency in terms of results and optimality in terms of costs, guaranteed achievement of the planned learning goal), 
Olga A. Poselennova, Margarita A. Kovardakova, Irina V. Aryabkina, Yulia A. Chernova, Kirill O. Ravodin.

reproducibility (the possibility of repetition by another teacher) and providing comfortable conditions for all the subjects of the educational process.

The criterion-diagnostic block includes a criterion apparatus, the characteristics of the formation levels of creative self-presentation skills.

The motivational-value criterion implies the formation of the motives of self-presentation (demonstration of one's belonging to the profession, raising one's own professional attractiveness, uniqueness, obtaining approval, professional self-assertion, professional self-identification, etc.), awareness of the values and significance of the chosen profession, professional culture, professional creativity.

The cognitive criterion allows establishing the completeness and depth of knowledge about business interaction, business etiquette, professional communication, about the structure of creative self-presentation, its strategies and tactics, as well as an idea of the meaning and functions of creative self-presentation in the professional activity of a specialist in mass information activities, the formation of thinking processes ( analysis, generalization, synthesis, judgments and inferences, etc.), allowing the individual to develop stable ideas about himself.

The regulatory (emotional-volitional) criterion is connected to the formation of emotional sensitivity, the development of a sense of empathy, possession of the skills of tolerant communication in the process of professional communication, emotional-volitional selfcontrol, management of one's psycho-emotional state in the course of self-presentation.

The activity criterion reflects the possession of skills and methods in the field of preparation, implementation, correction of self-presentation activities and involves the determination of the goal of self-presentation, the selection of the content for creative selfpresentation, the choice of its form, strategy and tactics, presentation of selected information using verbal and non-verbal means, analysis of self-presentation and the need for its correction.

The introspective criterion provides for the presence and content of self-analysis and self-reflection about self-presentation, i.e. the development of the ability to conduct selfanalysis, the search for one's strengths and weaknesses, the level and adequacy of selfesteem, the aspiration for self-development, the ability to recognize the emotional state of another person, recognition of the reaction of the recipient (an individual or collective subject who receives a message in the media communication process), orientation towards it.

The ability to attain creative self-presentation passes through the following levels in its development: critical, imitative, productive, situational-creative ones. 
¿eduweb

Revista de Tecnología de Información y Comunicación en Educación • Volumen 15, № 2. Mayo-agosto 2021

The block "Pedagogical conditions". In the course of the study, we formulated three groups of pedagogical conditions that ensure the success of the formation of creative selfpresentation skills of students preparing for work in the field of mass communication.

Organizational and pedagogical conditions embrace: scientific and methodological support of the process of forming creative self-presentation skills; technical equipment of the pedagogical process aimed at developing the skills of creative self-presentation; integration of the process of forming the ability to represent oneself in a holistic educational system for training specialists in the field of the mass media; pedagogical monitoring of the formation of creative self-presentation skills; the partnerships available between the university and various media; the transition from knowledge-based to competence-based approach in training specialists.

The group of psychological and pedagogical conditions includes: the development of a creative sphere in the process of education; subject-subject relations in the systems: "teacher-student", "student-student"; the development of positive motivation for the formation of creative self-presentation skills; creating a situation of success in the process of preparing creative self-presentation; individual approach to the student's personality; professional competence of the teacher, his mastery of the skills of creative selfpresentation; the formation of the value attitude of students to the creation of their own positive image as a future specialist in mass information activities and his creative selfpresentation; pedagogical support for the formation of creative self-presentation skills; demonstration of the prospects and significance of creative self-presentation skills in future professional activities.

The group of didactic conditions incorporates: the use of a variety of active and interactive technologies for the formation of creative self-presentation skills; modeling in the educational process situations that require the use of creative self-presentation skills; the use of modern educational technologies in the learning process that correspond to the goals and objectives of the formation of creative self-presentation skills; strengthening the integration of the subject content of such disciplines as the basics of communication theory, communication management, professional ethics, intercultural communication and mass media, speech technology, psychology and labor psychology; organization of collective forms of activity and various forms of cooperation of students in the process of developing creative self-presentation skills.

\section{Methodological Framework}

The experimental verification of the effectiveness of methodological and technological approaches to the formation of creative self-presentation skills was carried out at Ulyanovsk State University, I.N. Ulyanov Ulyanovsk State Pedagogical University and FSBEI VE Ulyanovsk State Technical University in 2016-2020. The experiment was carried out with students studying in such courses as "Journalism" and "Public Relations". 
Olga A. Poselennova, Margarita A. Kovardakova, Irina V. Aryabkina, Yulia A. Chernova, Kirill O. Ravodin.

One hundred and ninety-four students participated in the study: 96 people in the control group, and 98 people in the experimental group.

The experimental work was carried out in three stages.

Stage I - ascertaining. Its purpose was to identify the initial level of the formation of creative self-presentation skills among the students of I.N. Ulyanov Ulyanovsk State Pedagogical University and FSBEI VE Ulyanovsk State Technical University (courses: "Journalism" and "Public Relations").

Stage II - formative, included the implementation of a developed process model for the formation of creative self-presentation skills. A set of traditional for higher education at the university pedagogical technologies was used to ensure the successful formation of creative self-presentation skills of students mastering professional mass information activities (problem lecture, double lecture, lecture-visualization, lecture with pre-planned errors, lecture-conversation, lecture-discussion, lecture with analysis of specific situations, lecture-consultation, lecture-press conference) and innovative interactive technologies (role-playing, case-study, portfolio, storytelling, training)united by a common goal and meeting criteria such as conceptuality, systematics, manageability, results efficiency and cost optimality, assurance of achievement of the planned training goal, reproducibility.

Stage III - control, included re-diagnostics of the formation of creative self-presentation skills; generalization of the results of the pedagogical experiment to test the effectiveness of the approved model for the formation of creative self-presentation skills among students - future specialists in mass information activities.

To assess the formation of creative self-presentation skills during the ascertaining and control stages of the experiment, the motivational structure of the students' personality was explored, diagnostics of students' readiness to use creative self-presentation skills in professional activity was carried out; the levels of communication skills of students as future specialists in mass information activities, their creativity, reflexivity were determined.

The following diagnostic tools are of interest:

- diagnostics of personal creativity developed by E.E. Tunik (2006), used to assess riskiness, curiosity, level of imagination and a tendency to choose complex, nonstandard ideas;

- diagnostics of introspection by A.V. Karpov (2003), which determines the level of development of introspection among students.

Cluster analysis of the obtained experimental data was carried out to identify the level of formation of creative self-presentation skills among future specialists in mass information activities at the ascertaining and control stage of the experiment.

220 Creative self-presentation skills among students in the educational process of a higher education institution. Eduweb, 2021, mayo-agosto, v.15, n.2. /208-228 
Cluster analysis allows one to simplify the process of data processing and decision making by applying its own analysis method to each cluster. When analyzing the results of the work, the analysis was carried out using the methods of a hierarchical agglomerative family, namely the Ward method, in which the minimum variance is optimized within the clusters, as a result, clusters of approximately equal sizes are created (Mandel,1988).

The uniform standardization of measurement scales of objects is the condition of obtaining objective data in cluster analysis, in other words, bringing all the indicators to a single range of change.

The procedure of bringing the scales of indicators to one scale ensures the equivalence of all indicators when calculating the distance between individual measurements and conducting cluster analysis. To this end the coefficients of dimensions were introduced for each of the indicators: the formation of the motivation and value component (indicator $\mathrm{B}_{1}$ ), the cognitive component (indicator $\mathrm{B}_{2}$ ), the emotional and volitional component (indicator $\mathrm{B}_{3}$ ), the activity component (indicator $\mathrm{B}_{4}$ ), the introspective component (indicator $\mathrm{B}_{5}$ ) The coefficient of each indicator $\left(\mathrm{K}_{\mathrm{i}}\right)$ was calculated by means of dividing 10 by the maximum point. The derived point was calculated according to the formula: $P_{i}=K_{i}$ ${ }^{*} B_{i}$.

The data were calculated for each subject separately. The result was a matrix with dimensions 194x5 (194 - the number of respondents, 5 - the number of indicators). Numerical results were subjected to cluster analysis in accordance with the previously described technique. As a result, 4 clusters or groups with a reliability rate of $92 \%$ were obtained:

Level 1, critical - four indicators, for example, $B_{1}, B_{2}, B_{3} B_{4}$ have very low values, and one indicator $\left(B_{5}\right)$ - a low or a very low value;

Level 2, imitative - two or three indicators, for example, $\left(B_{1}, B_{2}\right.$ and $\left.B_{3}\right)$ or $\left(B_{1}\right.$ and $\left.B_{4}\right)$ have only low values, and the rest of the indicators $\left(B_{5}\right)$ or $\left(B_{4}\right.$ and $\left.B_{5}\right)-$ an average or a low value;

Level 3, productive - three or four indicators, for example, $\left(B_{1}, B_{2}, B_{3}\right.$ and $\left.B_{4}\right)$ or $\left(B_{1}, B_{2}\right.$ and $\left.B_{3}\right)$ have an average value and the rest of the indicators $\left(B_{5}\right)$ or $\left(B_{4}\right.$ and $\left.B_{5}\right)-$ an average or a high value;

Level 4 , situational-creative - three or four indicators, for example, $\left(B_{1}, B_{2}, B_{3}\right.$ and $\left.B_{4}\right)$ or $\left(B_{1}, B_{2}\right.$ and $\left.B\right)$ have a high value, and the rest of the indicators $\left(B_{5}\right)$ or $\left(B_{4}\right.$ and $\left.B_{5}\right)-a n$ average or a high value.

Accordingly, the formation levels of creative self-presentation skills among future specialists of mass information activities are in the following ranges of values: 
- from 0 to 50 - very low;

- from 51 to 149 - low;

- from 150 to 213 - average;

- from 214 to 255 - high.

Based on the characteristics of the data for clusters and the range of values, we have identified four formation levels of creative self-presentation skills among students - future specialists in mass information activities:

The critical level: the motives of self-presentation are not formed, the student is characterized by a weak awareness of the value and significance of the chosen profession, professional culture and creativity; knowledge about business interaction and professional communication is fragmentary, unclear, inaccurate, there is false knowledge, the idea of the importance and necessity of applying the skills of creative self-presentation in professional communication is insufficient; ideas about the structure, strategies and tactics of creative self-presentation are incomplete; a low level of thinking processes, which does not allow the student to develop stable ideas about himself; emotional sensitivity is poorly developed, a sense of empathy is rarely manifested, the skills of tolerant communication and emotional-volitional control are not demonstrated in the process of professional communication; the ability to use introspection is not developed, self-esteem is inadequate; recognition of the emotional state of other people is hindered, the recipient's reaction to his self-presentation is interpreted incorrectly; self-presentation activity is not very successful.

The imitative level: the motives of self-presentation are partially formed, the most often manifested is the motive of obtaining the teacher's approval; the values of professional activity, professional culture, professional creativity are realized, but their rank in the hierarchical structure of values of the student's personality is low; knowledge of business interaction and professional communication, strategies and tactics of creative selfpresentation are superficial, the idea of the importance and necessity of its application in professional communication is partially formed; emotional sensitivity and a sense of empathy are manifested episodically, the skills of tolerant communication and emotionalvolitional self-control in the process of professional communication are rarely demonstrated; introspection skills are poorly developed, self-esteem is not optimal; the qualities and state of a particular person are not always independently recognized, the student uses the methods of winning somebody's favor through verbal and non-verbal communication channels with diffidence; demonstrates typical ways of building selfpresentation, at this level, the student builds it according to the model, imitating the teacher, other students; does not always correctly interpret the reaction of the recipient to his self-presentation.

The productive level: a person realizes the value and significance of the chosen profession, professional culture, professional creativity, the range of motives for selfpresentation is quite wide; knowledge about business interaction, business etiquette, professional communication, about the structure of creative self-presentation, its 
strategies and tactics, as well as an understanding of the meaning and functions of creative self-presentation in the professional activity of a specialist in mass information activities are accurate and complete, thinking processes are sufficiently developed; emotional sensitivity and a sense of empathy are manifested when it is necessary, the skills of tolerant communication and emotional-volitional self-control in the process of professional communication are used in a stereotyped manner; the student quickly and accurately recognizes the qualities and state of a particular person, actively uses the methods of winning somebody's favor through facial expressions, intonations, studied during the course of training, quite successfully carries out self-presentation according to the proposed plan, algorithm, recognizes the recipient's reaction to his self-presentation, but he cannot always successfully correct it.

The situational-creative level: the motives of creative self-presentation are fully formed, a high rank of values of professional activity, professional culture, professional creativity in the hierarchical structure of values of the student's personality; knowledge about business interaction, business etiquette, professional communication, about the structure of creative self-presentation, its strategies and tactics, as well as an understanding of the meaning and functions of creative self-presentation in the professional activity of a specialist in mass information activities, is systemic and complete; thinking processes that allow a person to develop stable ideas about themselves are formed in a certain way; the ability to use introspection is developed, the assessment of one's strengths and weaknesses is adequate; the person possesses the skills of tolerant communication and emotional-volitional self-control at a high level in the process of professional communication; the student is characterized by the desire for self-development, the ability to understand the emotional state of another person; quickly recognizes the recipient's reaction, focuses on it, finds new means for building self-presentation, his creative manifestations are unique, self-presentation is effective.

\section{Results and Discussions}

The distribution of respondents by the levels of creative self-presentation skills convincingly testifies to the significant positive dynamics in the formation of creative selfpresentation skills among students of the experimental group (see Table 1).

Table 1. Distribution of respondents by the levels of the skill formation of creative selfpresentation in the experimental and control groups

\begin{tabular}{lllllllll}
\hline \multirow{2}{*}{ Groups } & \multicolumn{2}{l}{ Experimental group } & \multicolumn{7}{l}{ Control group } \\
\cline { 2 - 9 } Levels & Stage I & & Stage III & & Stage I & \multicolumn{3}{c}{ Stage III } \\
\cline { 2 - 9 } Critical & People & $\%$ & People & $\%$ & People & $\%$ & People & $\%$ \\
\hline Imitative & 26 & 26,5 & 10 & 10,2 & 30 & 31,3 & 25 & 26 \\
\hline Productive & 53 & 54,1 & 30 & 30,6 & 48 & 50 & 53 & 55,2 \\
\hline Situational-creative & 15 & 15,3 & 33 & 33,7 & 13 & 13,5 & 12 & 12,5 \\
\hline
\end{tabular}


Olga A. Poselennova, Margarita A. Kovardakova, Irina V. Aryabkina, Yulia A. Chernova, Kirill O. Ravodin.

A comparative analysis of the obtained data at the recording and control stages of the experiment suggests that the results of the students of the experimental group are significantly higher. The number of students who achieved the situational-creative level of formation of creative self-presentation skills increased by $21.4 \%$ (from $4.1 \%$ to $25.5 \%$ ), in the control group this indicator increased by only $1.1 \%$ (from $5.2 \%$ to $6.3 \%$ ). The number of students with a productive level of formed skills in the experimental group increased by $18.4 \%$ (from $15.3 \%$ to $33.7 \%$ ), in the control group decreased by $1 \%$ (from $13.5 \%$ to $12.5 \%$ ). The percentage of respondents with imitative level decreased in the experimental group (by 23.5\%), and increased in the control group (by $5.2 \%$ ). The number of students remaining at the critical level in the experimental group decreased by $16.3 \%$, in the control group this indicator decreased not so significantly - by $5.3 \%$.

The results of experimental work were confirmed using the method of mathematical statistics, such as the multifunctional statistical F-criterion by Fisher, which is designed to compare two samples by the frequency of occurrence of the effect under study. Using it, the validity between the initial and final quantitative data (in\%) obtained at the ascertaining and control stages of the experiment was checked. The obtained data $(2,304)$ is higher than the corresponding critical value for the level of $1 \%$, differences between groups are significant already at the level of $1 \%$.

Thus, the results of experimental testing of the process model and the pedagogical conditions for the formation of creative self-presentation skills among students - future specialists in the field of mass information activities indicate their effectiveness.

In general, our research results can be divided into theoretical and practical ones. The theoretical ones include a more precise definition of such concepts as "professional selfpresentation", "creative self-presentation", the definition of the basic set of creative selfpresentation skills and a description of the conditions for their formation. We refer an increase in the level of mastery of creative self-presentation skills among students, future specialists in mass information activity to the practical results, which will significantly raise their competitiveness level on the labor market.

\section{Conclusion}

Summarizing the materials presented in the paper, one can draw the following conclusions:

1. Professional mastery and competence of a specialist in the field of mass information activities is assessed by what creative skills and abilities he possesses. The quality of labor activity of a specialist of this profile, his professional success and demand on the labor market depend on the degree of their development.

2. Professional self-presentation is an important component required in the professional activity of a specialist in mass information activities. Professional self-presentation is an uninterrupted process that the communicants may not be aware of, but, nevertheless, serves to convey information about the personality of the subject as a 
Gduweb

Revista de Tecnología de Información y Comunicación en Educación • Volumen 15, Nㅜ 2. Mayo-agosto 2021

professional in his field. This can comprise both personal qualities that, in the opinion of the subject, are relevant to work in this field of activity, and information about the knowledge, experience, skills of the subject, which, in his opinion, are important for this profession.

3. Creative self-presentation of a specialist in mass information activities represents such communicative actions that help the subject to reveal his creative potential, through regulatory actions to find his place in the chosen area and a specific team, through reflection to continue self-development in the chosen professional area.

4. Creative self-presentation skills as well-formed and stabilized modes of action include several components: a motivational, cognitive, emotional-volitional, activity and introspective one. The skills of creative self-presentation of specialists in the field of mass information activities embrace: skills in establishing contacts, keeping the listener's attention; the ability to win other people's favor demonstrating respect and trust in the interlocutor, sincerity, spontaneity, interest; introspection and self-reflection skills; self-regulation skills; skills of verbal and non-verbal communication, civilized psychological influence; possession of various tactics of creative self-presentation; the ability to focus on a person, his emotions and feelings; skills of mobilization and adaptation to the communication situation; artistic skills; business etiquette skills.

5. In the course of the experiment to ascertain the facts, it was found that students do not sufficiently possess the skills of creative self-presentation as an element of the professional communicative culture of a specialist in the field of mass media, have a poor understanding of the strategies and tactics of self-presentation, demonstrate a low level of formation of creative self-presentation skills, which confirms the need for purposeful work on their formation in the educational process of a higher education institution.

6. The process of forming the skills of creative self-presentation among future specialists in mass information activities should be carried out in two parallel directions: sociopedagogical (the acquisition of knowledge underlying effective self-presentation, teaching self-presentation skills through the creation of a set of didactic conditions) socio-psychological (development and improvement of creative self-presentation skills carried out in the conditions of group educational and training activities).

7. Teaching creative self-presentation in the educational process of a higher education institution contributes to: the formation and further development of the student's motivational sphere; activation of self-development and self-actualization of the personality of the future specialist in mass information activities; realization of the student's creative potential; encouraging the student to represent creatively his own "Self"; the development of existing personal characteristics and evolvement of new qualities, such as initiative, critical mind, openness to new things, the need to find new ways to solve professional problems, independence in choosing the necessary methods to achieve professional goals and solve professional problems.

8. The process model of the formation of creative self-presentation skills developed in the course of the research among students - future specialists of mass information activities in the educational process of a university made it possible to consider the process under study comprehensively and mentally reflect its goals, content, 
structure, connections and results, combining the target, methodological, content, criterion-diagnostic blocks, as well as a block of pedagogical conditions into a holistic system.

9. The use of a complex of pedagogical technologies contribute to attaining the goal of forming the creative self-presentation skills of a future specialist in mass information activities in the process of studying at a higher education institution. These technologies meet such criteria as conceptuality (reliance on a specific scientific concept); consistency (possession of all the features of the system), controllability (opportunities for goal-setting, planning, educational process, monitoring, variation of methods and means of teaching in order to correct its results), efficiency (efficiency in terms of results and optimality in terms of costs, guaranteed achievement of the planned learning goal), reproducibility (the possibility of repetition by another teacher) and providing comfortable conditions for all subjects of the educational process.

10. The results of the experimental work confirm the effectiveness of the model of the process of forming creative self-presentation skills among future specialists in mass information activities during their training at a higher education institution and pedagogical conditions of their implementation. The statistical significance of positive changes in the state of the studied skills among students of the experimental groups, which occurred, as a result of the formative experiment, was established on the basis of the selected criteria at the stage of the control experiment.

11. Promising areas for further research into the problem of forming creative selfpresentation skills of future specialists in mass information activities are: studying the ways of developing creative self-presentation skills formed previously, searching for new pedagogical technologies that contribute to the development of creative selfpresentation skills, studying the features of using creative self-presentation skills in the context of remote interaction.

\section{References}

Abulkhanova-Slavskaya, K. A. (1991). Strategy of life. Moscow: Mysl.

Avdeeva, N.N. (2009). Big psychological dictionary. Moscow: AST; St. Petersburg: PrimeEvroznak.URL:https://spbguga.ru/files/03-5-01-005.pdf.

Bernstein, N.A. (2012). On the construction of movements. M.: Book on demand.

Brigadnova, A.Yu. (2012). Technology of forming readiness for self-presentation in the process of practical training. Bulletin of the RMAT, No. 2-3 (5-6), pp. 114-119.

Budnikova, S. P., Radchenko, S. A., Prosperova, N. V., Lukienko, L. V., Pazukhina, S. V., Radchenko, S. S., Ryabov, R. G., Petrova, M. S., (2016). Developing practical skills for life safety, improving employment and caree. Tula: Tula State Pedagogical. University named after L. N. Tolstoy. ISBN 978-5-87954-997-3.

Davydov, V.V. (2004). Problems of developing learning: the experience of theoretical and experimental psychological Research. Moscow: Academy

Galperin, P. Ya., Talyzina, N.F. (1972). Guiding cognitive activity of students. Moscow: Moscow State University. URL:https://search.rsl.ru/ru/record/01007077471.

Glotova, E.E. (2015). Self-presentation of a university graduate as one of the ways of effective employment. Problems of pedagogy, No. 2 (3), pp. 178-181. 


\section{๔eduweb}

Revista de Tecnología de Información y Comunicación en Educación • Volumen 15, N² 2 Mayo-agosto 2021

Gretsov, A.G. (2003). Emotional relationships with peers and psychological problems of adolescents (the abstract of the thesis for PhD in Psychology), The Herzen State Pedagogical University of Russia, St. Petersburg. URL: https://search.rsl.ru/ru/record/01002648113.

Karpov, A.V. (2003). Reflexivity as a mental property and the method of its diagnosis. Psychological journal, № 5, pp. 45-57. ISSN 0205-9592.

Kasatkina, A. Yu. (2011). The ways of self-identification and self-presentation of the subject of professional activity. Bulletin of ChelSU, No. 24, pp. 235-237.

Kazantseva, E.V. (2013). The formation of self-presentation skills as professionally required qualities of future educational psychologists. Concept, No. 5, pp. 1-3.

Klimenko, A. A., Khazova, S. A., Karaseva, S. A. (2018). Self-presentation competence: the content and formation bases: textbook. Krasnodar: KubSAU. ISBN 978-500097-571-8-164.

Koryagina, N. A. (2012). Research problems of socio-psychological factors of selfpresentation. Modernization of Russian education: trends and prospects. Book 3: monograph, Krasnodar: Center for Social and Political Research "Premier", pp. 24-44.

Krylov, E. Yu. (2012). The formation of tactics of purposeful self-presentation among students in a virtual environment: (the abstract of the thesis for PhD in Psychol). Sciences: spec, Herzen State Ped. University, St. Petersburg.

Mandel, I.D. (1988). Cluster analysis. Moscow: Finance and statistics.

Mikhailova, E. V. (2006). Teaching self-presentation: textbook: [for students and graduate students studying psychology]. Higher School of Economics. 2nd ed., Moscow: SU HSE. ISBN 5-7598-0433-2.

Mishina, I.I. (2018). Professionally oriented model of the formation of readiness of students of non-humanities programs for speech self-presentation (the abstract of the thesis for PhD in Pedagogy). Peoples' Friendship University of Russia, Moscow, http://www.dslib.net/teoria-vospitania/professionalno-orientirovannajamodel-formirovanija-gotovnosti-studentov.html

Novitskaya, N. G, Barash, I. N. (2014). Self-presentation in foreign language communication and teaching technology in English lesson. Bulletin of Mozyr State University named after I. P. Shamyakin, Mozyr, No. 2 (43), pp. 117-120.

Panasenko, K.E. (2005). Specific features of self-presentation among preschoolers with speech impairment: the thesis for PhD in Psychology, Federal State Autonomous Educational Institution of Higher Education «Belgorod State National Research University», Belgorod. URL: https://www.dissercat.com/content/osobennostisamoprezentatsii-doshkolnikov-s-narusheniem-rechevogo-razvitiya.

Pochkai, E.P. (2016). Amateur journalism as a means of self-realization. International research journal, No. 1(55), Part 3, pp. 136-139.

Ponomarenko, I.V. (2008). Socio-psychological features of self-presentation of women in the military (the abstract of the thesis for PhD in Psychology), The Military University of the Ministry of Defense of the Russian Federation, Moscow. URL: https://www.dissercat.com/content/sotsialno-psikhologicheskie-osobennostisamoprezentatsii-voennosluzhashchikh-zhenshchin. 
Savateyev, A.V. (2001). Psychological conditions for improving the image of the commander of the cadet sub-unit (the abstract of the thesis for PhD in Psychology), Military University, Moscow. https://www.dissercat.com/content/psikhologicheskie-usloviyasovershenstvovaniya-imidzha-komandira-kursantskogo-podrazdeleniya

Savin, V. A. (2012). Didactic basis for the development of self-presentation as a component of the professional success of a future specialist. Russian psychological journal, Vol. 9, No. 2, pp. 55-61. Text: electronic. URL: http://www.rpj.ru.com.

Semyonova, L.M. (2008). The formation of a professional image and readiness for selfpresentation among future specialists in the field of mass communication: monograph. Chelyabinsk: South Ural State University Publishing House.

Sheverdina, O.V. (2006). Pedagogical conditions for the formation of the experience of a teenager's self-presentation in a temporary summer association (the abstract of the thesis for PhD in Pedagogy), Nekrasov Kostroma State University, Kostroma. URL: $\quad$ https://www.dissercat.com/content/pedagogicheskie-usloviyaformirovaniya-opyta-samoprezentatsii-podrostka-vo-vremennom-letnem-.

Shishkova, M.G. (2013). Organization of self-presentations of future skilled workers in professional development. International research journal, No. 6 (6), pp. 66-67.

Tunik, E.E. (2006). Diagnosis of creativity. E. Torrens test: adaptive. St. Petersburg: Speech, 175 p. - ISBN 5-9268-0461-2.

Vaganova, O., Ilyashenko, L., Smirnova, Z., Bystrova, N., \& Kaznacheeva, S. (2019). Students' creative abilities development in higher educational institution. Amazonia Investiga, 8(22), 701-710. Retrieved from https://amazoniainvestiga.info/index.php/amazonia/article/view/822

Vaganova, O., Livshits, Y., Aleshugina, E., Smirnova, Z., \& Kutepova, L. (2019b). Experience in developing electronic glossary in a higher education institution. Amazonia Investiga, 8(22), 247-253. Retrieved from https://amazoniainvestiga.info/index.php/amazonia/article/view/421

Zhukov, Yu. M. (2003). Training as a method of improving communicative competency. (The thesis for Doctoral Degree in Psychology). Moscow State University, Moscow. URL: https://www.dissercat.com/content/trening-kak-metodsovershenstvovaniya-kommunikativnoi-kompetentnosti.

Zakharova, I.B (2003). Socio-pedagogical orientation of the student's personality to successful self-presentation in the educational process. (The thesis for Doctoral Degree in Pedagogy). Reshetnev Siberian State University of Science and Technology, Krasnoyarsk. URL: https:/www.dissercat.com/content/sotsialnopedagogicheskoe-orientirovanie-lichnosti-studenta-na-uspeshnuyusamoprezentatsiyu-. 